\title{
Valoración puzolánica de la hoja de la caña de azúcar
}

\section{Pozzolanic evaluation of the sugar cane leaf}

\author{
A. Guzmán(*), C. Gutiérrez(*), V. Amigó(**), R. Mejía de Gutiérrez ${ }^{(*)}$, S. Delvasto(*)
}

Recepción/Received: 14-IX-09

Aceptación/Accepted: 22-III-10

Publicado online/Online publishing: 20-VI-11

\section{RESUMEN}

En el siguiente artículo se presenta una evaluación de la hoja de caña de azúcar calcinada bajo condiciones controladas en aras a obtener ceniza reactiva (con propiedades puzolánicas). La ceniza fue analizada mediante las técnicas de difracción de rayos $X$, fluorescencia de rayos $X$ y microscopía electrónica de barrido. Los resultados del estudio mostraron que la ceniza de hoja de caña de azúcar sí contiene una significante presencia de material amorfo y un alto porcentaje de sílice $(81,0 \%)$. Se valoró la aptitud de las cenizas obtenidas como puzolana mediante métodos químicos, como el ensayo de Frattini y métodos mecánicos, como el índice de actividad puzolánica. Como modelo a seguir para la interpretación de la puzolanicidad de la ceniza de hoja de caña se utilizó el método de Feret. Se concluye que la ceniza de hoja de caña sí es apta para ser utilizada como adición puzolánica.

Palabras claves: puzolana, cemento Portland, material amorfo, hidróxido de calcio, mortero.

\begin{abstract}
This paper presents the results of the evaluation of the sugarcane leaf, burnt under controlled conditions in order to obtain a reactive ash with pozzolanic properties. Chemical analysis, amorphousity and surface structure of the sugar cane straw ash (SCSA) were studied by $X$-ray diffraction, X-ray fluorescence spectroscopy and scanning electron microscope (SEM). The results of this research showed that SCSA has significant presence of amorphous material and a high content of silica (81.0\%). The pozzolanic activity of the SCSA was evaluated by the Fratini test and the pozzolanic activity index. In order to interpretate the pozzolan activity, the Feret method was used. It is conclude that the SCSA presents pozzolanic characteristics for blending Portland cement.
\end{abstract}

Keywords: pozzolan, Portland cement, amorphous material, calcium hydroxide, mortar.

\section{INTRODUCCIÓN}

En el valle geográfico del río Cauca se obtendrían potencialmente más de 5 millones de toneladas de hojas de caña de azúcar en 200.000 hectáreas cultivadas, que es una cantidad bastante elevada para un desecho, que urgiría aprovechar, dado que su combustión incontrolada a cielo

\section{INTRODUCTION}

The River Cauca Valley, with over 200000 hectares of sugar cane fields, potentially generates upward of five million tonnes of sugar cane straw. A dire need to re-use such large quantities of waste has been identified, given the severe environmental problems occasioned by its

\footnotetext{
(*) Universidad del Valle (Cali, Colombia).

(**) Universidad Politécnica de Valencia (Valencia, España).
} 
abierto en el campo está generando problemas ambientales muy severos (1). Por situaciones como ésta, desde hace algunos años se ha venido investigando la utilización potencial de los residuos de materiales vegetales (tallo, raíz, hojas, cáscara, principalmente) provenientes de plantas de cultivos como el arroz, el café y la caña de azúcar. Es así como la generación de energía eléctrica mediante el proceso de cogeneración ha sido una alternativa para gran parte de la biomasa generada. Se afirma que de 6 millones de toneladas de bagazo, subproducto derivado de procesos de cosecha y molienda de la caña de azúcar, producidas al año por los ingenios, un $85 \%$ es utilizado como combustible primario en calderas y el restante $15 \%$ se ha convertido, debido a su contenido en celulosa, en materia prima para la industria local productora de papel (1). Es de anotar, que a la fecha el aprovechamiento de las hojas y otros residuos de la cosecha es incipiente.

En Colombia, diversas instituciones, entre las cuales se encuentran la Universidad del Valle con el Grupo de Investigación de Materiales Compuestos y la Universidad del Cauca con el Grupo CYTEMAC, han desarrollado estudios sobre la composición química y posibles usos de las cenizas de la cascarilla de arroz y el bagazo, ya que éstas se presentan en contenidos bastante elevados, con porcentajes de 22,15 y $14,71 \%$, respectivamente. A partir del análisis de la ceniza se ha encontrado que el mayor porcentaje de sus partículas está compuesto por sílice con contenidos del orden de $93 \%$ y $73 \%$ para la cascarilla de arroz y el bagazo, respectivamente. En concreto, en el caso de la sílice extraída de la cascarilla de arroz se han reportado aplicaciones en diversos campos de la industria $(2,3)$.

El bagazo de la caña de azúcar ha sido investigado, tanto como materia prima o como material puzolánico, para su uso en la manufactura de cementos comerciales y otros compuestos (4-6). La utilización como puzolana de los desechos de la agricultura requiere calcinación previa, pero la actividad puzolánica varía sustancialmente como resultado de las condiciones de calcinación y la naturaleza de los materiales de origen. Es así, que existen resultados contradictorios acerca de la efectividad puzolánica de la ceniza del bagazo de caña de azúcar (Sugar Cane Bagasse Ash, SCBA) que se atribuyen al empleo de diferentes temperaturas de calcinación (7-9). En cuanto a la ceniza de la hoja de caña de azúcar (Sugar Cane Straw Ash, SCSA), tanto obtenida a partir de hojas calcinadas a cielo abierto en las vecindades de una fábrica de azúcar (5-7) como en hornos rudimentarios $(5,6,10)$, similares a los incineradores construidos en Asia para producir ceniza de cascarilla de arroz, se obtiene una significativa presencia de material amorfo (vítreo) y alta actividad puzolánica. Algunos investigadores han desarrollado modelos matemáticos para describir el proceso, tanto en el régimen cinético como en el cinético-difusivo, permitiendo determinar los parámetros que caracterizan el proceso y la cinética de la reacción puzolánica (11-14). uncontrolled open-air incineration (1). In light of this and similar situations, research has been underway in recent years on the potential use of plant waste (primarily stems, roots, leaves and husks) from crops such as rice, coffee and sugar cane. One alternative for a substantial part of this waste has been the co-generation of electric power. Around $85 \%$ of the six million tonnes of bagasse produced yearly in sugar cane harvesting and milling is estimated to be used as a primary fuel in boilers and the remaining $15 \%$ as a raw material for the local paper industry, in light of its cellulose content (1). At this writing, however, the re-use of straw and other harvest waste has yet to be fully explored and developed.

In Colombia a number of institutions, including Valle University's Composite Materials Research Group and the University of Cauca's CYTEMAC group, have conducted studies on the chemical composition and potential use of rice husk and bagasse, because these agroindustrial wastes have a high content of ash (22.5 and 14.71\%, respectively). Ash analysis has shown that silica accounts for the highest percentage of its particles, with contents on the order of 93 and $73 \%$ for rice husk and bagasse, respectively. Moreover, applications have been found for the silica extracted from rice husks in a number of areas of industry $(2,3)$.

Sugar cane bagasse has been researched both as a prime material and as a pozzolan in the manufacture of commercial cements and other compounds (4-6). The use of agricultural waste as a pozzolan entails incineration, but pozzolanicity varies substantially depending on the incineration conditions and the nature of the source materials. As a result, the findings on sugar cane bagasse ash (SCBA) pozzolanicity are contradictory, a situation attributed to the use of different incineration temperatures (7-9). The sugar cane straw ash (SCSA) obtained by burning the material either in the open air in the proximity of a sugar mill (5-7) or in rudimentary kilns $(5,6,10)$ similar to the incinerators built in Asia to produce rice husk ash contains significant proportions of amorphous (vitreous) material and exhibits high pozzolanicity. A number of researchers have developed mathematical models to describe the kinetic and kineticdiffusive processes involved, from which they have determined the parameters that characterise the pozzolanic reaction and its kinetics (11-14). 
Este artículo presenta la evaluación de la puzolanicidad de la ceniza de hoja de caña $(\mathrm{CHC})$ obtenida mediante una combustión de la hoja a temperaturas inferiores a $427^{\circ} \mathrm{C}$ y una calcinación controlada hasta una temperatura máxima de $700{ }^{\circ} \mathrm{C}$ con un tiempo de permanencia de dos horas en esta temperatura. La ceniza se caracterizó mediante técnicas analíticas e instrumentales como Difracción de Rayos $X$ (DRX), Fluorescencia de Rayos X (FRX), Microscopía Electrónica de Barrido (MEB) y su aptitud puzolánica se valoró mediante métodos químicos como el ensayo de Frattini y métodos mecánicos como el índice de actividad puzolánica.

\section{MATERIALES Y DESARROLLO EXPERIMENTAL}

\subsection{Materiales}

En la presente investigación se trabajó con una variedad de caña común, que es la variedad más utilizada por los ingenios y haciendas del Valle del Cauca (Colombia), que se conoce como tipo Cenicaña Colombia 8592 (CC8592). Se hizo la recolección de las hojas de caña de azúcar de un cultivo extenso cercano a la ciudad de Cali, cuya edad de maduración era de 13 meses. Se utilizó cemento Portland sin adición y arena de Ottawa en conformidad con la norma ASTM C778-06 (15).

Previo a conocer el proceso de calcinación más apropiado para obtener una ceniza con un elevado contenido de sílice amorfa, se plantearon tres tipos de procesos como sigue:

1. Proceso A. Calcinación de la hoja a una temperatura máxima de $700{ }^{\circ} \mathrm{C}$ con un tiempo de permanencia de dos horas a esta temperatura.

2. Proceso B. Calcinación de la hoja a una temperatura máxima de $590^{\circ} \mathrm{C}$ con un tiempo de permanencia de dos horas.

3. Proceso C. Combustión previa de la hoja y una posterior calcinación controlada a una temperatura máxima de $700{ }^{\circ} \mathrm{C}$ con un tiempo de permanencia de dos horas.

El proceso con el que se obtuvieron los mejores indicios de puzolanicidad de la ceniza de hoja de caña fue el denominado Proceso $\mathrm{C}$, en el cual la ceniza se obtuvo mediante prequema de la hoja a temperaturas menores de $427{ }^{\circ} \mathrm{C}$ y una calcinación controlada a una temperatura máxima de $700{ }^{\circ} \mathrm{C}$ con un tiempo de permanencia de dos horas. Una vez calcinadas, las cenizas fueron llevadas a una finura similar a la del cemento Portland.

\subsection{Técnicas de Caracterización de la Ceniza}

La ceniza que se utilizó como adición puzolánica fue sometida a un proceso de molienda en un molino de bolas de laboratorio utilizando una relación de cuerpos
The present article reports on the assessment of pozzolanicity in sugar cane straw ash (SCSA) obtained by pre-combustion of the material at temperatures of under $427{ }^{\circ} \mathrm{C}$ and subsequent incineration for two hours at $700^{\circ} \mathrm{C}$. The ash was characterised by analytical and instrumental techniques such as X-ray diffraction (XRD), $X$-ray fluorescence (XRF) and scanning electron microscopy (SEM) and its pozzolanicity was measured chemically with the Frattini test and mechanically with the pozzolanic activity test.

\section{MATERIALS AND EXPERIMENTAL}

\subsection{Materials}

The variety of sugar cane used in the present study was Cenicaña Colombia 8592 (CC-8592), the variety most commonly found in Cauca Valley, Colombia, cane mills and plantations. Thirteen-month sugar cane straw was gathered from a large plantation near the city of Cali. Unadditioned Portland cement (OPC) and Ottawa sand were used, further to ASTM C778-06 (15) recommendations.

Three processes were tested to determine the most suitable incineration conditions for obtaining a high amorphous silica content, as listed below:

1. Process $A$. Straw incineration for two hours at a maximum temperature of $700^{\circ} \mathrm{C}$.

2. Process B. Straw incineration for two hours at a maximum temperature of $590^{\circ} \mathrm{C}$.

3. Process C. Straw pre-combustion and subsequent controlled incineration for two hours at a maximum temperature of $700^{\circ} \mathrm{C}$.

Process $C$ yielded the highest pozzolanicity indices for the sugar cane straw ash. In this procedure, prior to controlled incineration for two hours at a maximum of $700{ }^{\circ} \mathrm{C}$, the straw was pre-combusted at temperatures below $427^{\circ} \mathrm{C}$. After incineration, the ash was ground to fineness similar to that of Portland cement.

\subsection{Ash characterisation techniques}

The ash used as a pozzolanic addition was ground for one hour in a laboratory ball grinder fitted with fifty 2.26$\mathrm{cm}$ diameter and five 3.12-cm diameter balls. The Blaine 
moledores de 50 bolas de 2,26 cm de diámetro y 5 bolas de $3,12 \mathrm{~cm}$ de diámetro, por un tiempo de una hora. Al material obtenido se le determinó la Finura Blaine según la Norma NTC 33 (16) y la distribución granulométrica de sus partículas; este último ensayo se realizó en un equipo Mastersizer 2000. Cabe anotar, que el material inicialmente tenía un diámetro medio de partículas $D(4,3)$ de $55,68 \mu \mathrm{m}$ y luego de la molienda el diámetro medio se redujo a 24,16 $\mu \mathrm{m}$. Adicionalmente, se determinó su peso específico siguiendo el procedimiento descrito en la Norma Técnica Colombiana NTC 221 (17), en forma análoga al cemento. Su composición química fue determinada por FRX en un equipo PHILIPS, modelo PW 2400; y el contenido de sílice amorfa se realizó acorde al método propuesto por Metha (18) denominado Índice de Sílice Activa, el cual consiste en medir la proporción de sílice disuelta al poner en contacto el material con una solución de $\mathrm{NaOH}$ 0,5N durante 3 minutos a temperatura de ebullición. Como análisis complementarios se utilizaron las técnicas de difracción de rayos $X$ (DRX) y microscopia electrónica de barrido (MEB).

\subsection{Métodos de evaluación de la actividad puzolánica de la ceniza}

Método químico. La actividad puzolánica se determinó mediante el ensayo de Frattini, que corresponde al descrito en la Norma NTC 1512 (19) para edad de curado de 7 y 28 días.

Método mecánico. El Índice de Actividad Puzolánica fue evaluado siguiendo la Norma ASTM C311-07 (20) a edades de curado de 7 y 28 días.

Además del Índice de Actividad Puzolánica se valoró el efecto puzolánico de la adición mediante ensayos mecánicos (21), para lo cual se prepararon:

- Tres series de morteros con cemento sin adición puzolánica por cada edad, tomado como testigo o patrón (EMA 0\%).

- Tres series de morteros con cemento adicionado con ceniza de hoja de caña por cada porcentaje y cada edad, donde el cemento es sustituido por ésta en los siguientes porcentajes en peso: 5, 10, 20, 40\% (EMA 5\%, EMA $10 \%$, EMA $20 \%$ y EMA $40 \%$ ).

- Tres series de morteros con cemento adicionado con un material inerte (arena de Ottawa molida) por cada porcentaje y cada edad, donde el cemento es sustituido por éste en los siguientes porcentajes en peso: 5, 10, 20, 40\% (AOM 5\%, AOM 10\%, AOM 20\% y AOM 40\%).

La resistencia mecánica a la compresión fue evaluada a edades de curado estándar de 28 y 60 días donde se presume ya es perceptible el efecto puzolánico, y con fineness of the material was found as specified in Colombian standard NTC 33 (16) and its particle size distribution was determined on a Mastersizer 2000 analyser. The material initially had a mean particle diameter, $D$ (4.3), of $55.68 \mu \mathrm{m}$, which grinding reduced to $24.16 \mu \mathrm{m}$. The unit weight was also determined pursuant to the procedure described in Colombian technical standard NTC 221 (17) for cement. The chemical composition of the ash was established with a PHILIPS PW 2400 XRF spectrometer. Its amorphous silica content was found using the active silica index method proposed by Metha (18), which consists of measuring the proportion of dissolved silica when the material is immersed for 3 minutes in a boiling $0.5-\mathrm{N}$ solution of $\mathrm{NaOH}$. X-ray diffraction (XRD) and scanning electron microscopic (SEM) analyses were also conducted.

\subsection{Methods for evaluating ash pozzolanicity}

Chemical method.- Seven- and 28-day pozzolanicity values were determined with the Frattini test described in Colombian standard NTC 1512 (19).

Mechanical method.- The 7- and 28-day pozzolanic activity index was established as specified in standard ASTM C311-07 (20).

In addition to this index, the pozzolanic effect of the addition was assessed with mechanical tests (21), for which the following mortars were prepared:

- Three series of unadditioned cement mortars for each age, used as a control (0\% OPC).

- Three series of sugar cane straw ash-additioned cement mortars for each replacement ratio and age. The cement was replaced by the following percentages of the addition (by weight): $5,10,20$, $40 \%$, (5\% OPC, $10 \%$ OPC, $20 \%$ OPC and, $40 \%$ OPC).

- Three series of cement mortars additioned with (inert) ground Ottawa sand for each replacement ratio and age. The cement was replaced by the following percentages of the addition (by weight): 5, 10, 20, $40 \%$ (5\% GOS, $10 \%$ GOS, $20 \%$ GOS and $40 \%$ GOS).

Compressive strength was determined in specimens cured under standard conditions for 28 and 60 days, times at which the pozzolanic effect was assumed to be 
base en estos resultados se halló el coeficiente $K$ de Feret según la ecuación [1], haciendo uso de su método con el fin de determinar la calidad puzolánica (21). perceptible. The Feret $K$ coefficient was found with equation [1] on the grounds of these results to establish pozzolanic quality (21).

$$
K_{j}=R_{j}\left[\frac{\frac{C}{A}+\rho}{\frac{C}{A}}\right]^{2}
$$

Donde:

$\mathrm{Kj}=$ Coeficiente de energía del conglomerante.

$\mathrm{Rj}=$ Resistencia a la compresión a j días.

$\mathrm{C} / \mathrm{A}=$ Relación en peso cemento/agua.

$\rho=$ Densidad del conglomerante.

\section{RESULTADOS Y DISCUSIÓN}

\subsection{Caracterización ceniza obtenida}

Por medio del ensayo químico de solubilidad en medio alcalino desarrollado por Metha (18) se determinó el contenido de sílice amorfa el cual se presenta en la Tabla 1 y por difracción de Rayos X (Figura 1) se corroboró la amorficidad de las cenizas obtenidas. En estos resultados se puede apreciar que el proceso de calcinación $\mathrm{C}$, que incluye la prequema y posterior tratamiento térmico controlado a $700{ }^{\circ} \mathrm{C}$ permite obtener el material con mayor nivel de sílice amorfa. La composición química de la ceniza (véase Tabla 2), obtenida por fluorescencia
Where:

$K j=$ Feret's $K$ coefficient .

$R j=$ compressive strength at day $j$.

$C / W=$ cement/water ratio by weight.

$\rho=$ binder density.

\section{RESULTS AND DISCUSSION}

\subsection{Characterisation of the ash obtained}

The amorphous silica content values found with the alkaline solubility test developed by Metha (18) are given in Table 1. X-ray diffraction (Figure 1) corroborated the amorphous nature of the ash obtained. These findings showed that incineration process $C$, which included precombustion and subsequent controlled thermal treatment at $700{ }^{\circ} \mathrm{C}$, yielded the material with the highest amorphous silica content. According to the chemical composition of the ash (see Table 2) obtained with X-ray fluorescence $(X R F)$, the main component was $\mathrm{SiO}_{2}$, a

Tabla 1 / Table 1

Porcentaje de Sílice Amorfa.

Amorphous silica content (per cent).

\begin{tabular}{|c|c|c|}
\hline Tipo de ceniza / Type of ash & $\begin{array}{c}\text { Temperatura de calcinación }\left({ }^{\circ} \mathrm{C}\right) \text { / } \\
\text { Incineration temperature }\left({ }^{\circ} \mathrm{C}\right)\end{array}$ & \% Sílice amorfa / Amorphous silica (\%) \\
\hline A partir de la hoja / Directly from straw & 700 & 42 \\
\hline A partir de la hoja / Directly from straw & 590 & 37 \\
\hline $\begin{array}{c}\text { A partir de la prequema de la hoja / } \\
\text { From straw after pre-combustion }\end{array}$ & 700 & 57 \\
\hline
\end{tabular}

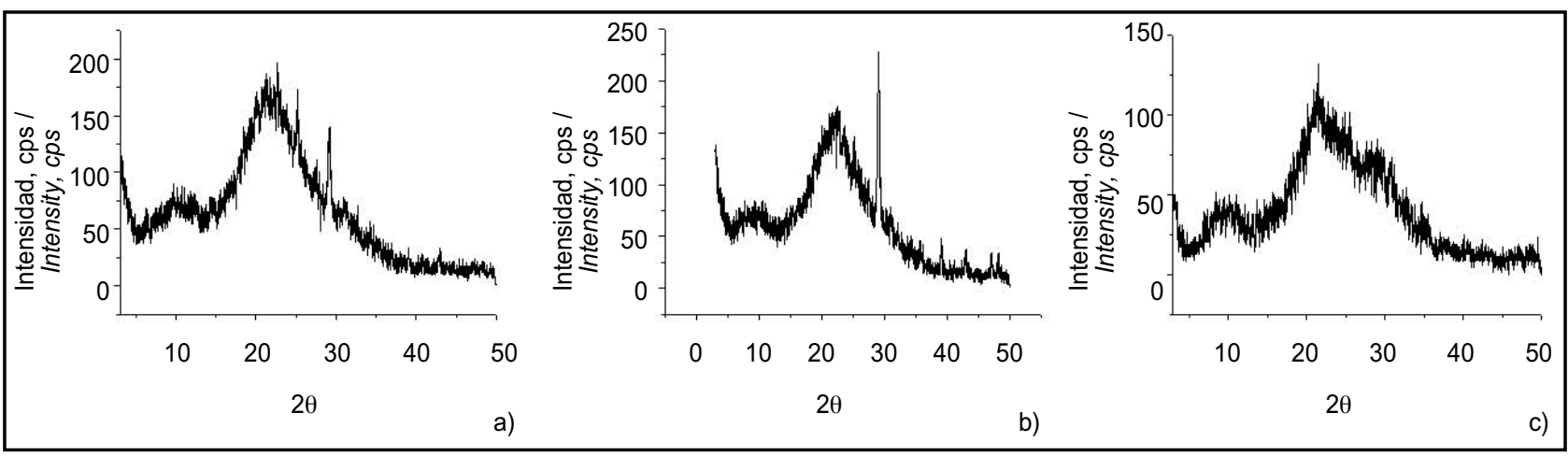

Figura 1. DRX de ceniza obtenida mediante el proceso de calcinación (a) $A,(b) B, y$ (c) C. Figure 1. XRD patterns for ash obtained with calcination processes (a) $A,(b) B$, and (c) $C$. 
de rayos $X(F R X)$, muestra como componente principal $\mathrm{SiO}_{2}$, lo cual corrobora resultados reportados por Martirena $(5,7)$ y Frías $(13)$; cabe anotar que estos valores son mayores en la ceniza obtenida en esta investigación. El peso específico de la ceniza fue de $2 \mathrm{~g} / \mathrm{cm}^{3}$. finding that concurred with the results reported by Martirena (5, 7) and Frías (13), although the values obtained in this study were higher. The unit weight of the ash was $2 \mathrm{~g} / \mathrm{cm}^{3}$.

Tabla 2 / Table 2

Composición química de la ceniza de hoja de caña. Chemical composition of sugar cane straw ash.

\begin{tabular}{|c|c|}
\hline Componente / Component & $\%$ \\
\hline $\mathrm{K}_{2} \mathrm{O}$ & 3.00 \\
\hline $\mathrm{Na}_{2} \mathrm{O}$ & 0.11 \\
\hline $\mathrm{CaO}$ & 6.00 \\
\hline $\mathrm{MgO}$ & 2.00 \\
\hline $\mathrm{Al}_{2} \mathrm{O}_{3}$ & 0.60 \\
\hline $\mathrm{SiO}_{2}$ & 81.0 \\
\hline $\mathrm{Fe}_{2} \mathrm{O}_{3}$ & 0.70 \\
\hline $\mathrm{TiO}_{2}$ & 0.04 \\
\hline $\mathrm{P}_{2} \mathrm{O}_{5}$ & 1.10 \\
\hline $\mathrm{SO}_{3}$ & 1.40 \\
\hline $\mathrm{MnO}$ & 0.08 \\
\hline $\mathrm{ZnO}$ & 0.03 \\
\hline $\mathrm{PPI} 110{ }^{\circ} \mathrm{C}$ a $1100{ }^{\circ} \mathrm{C}$ & 4.00 \\
\hline &
\end{tabular}

Las cenizas obtenidas fueron analizadas mediante Microscopía Electrónica de Barrido (MEB) tal como se muestra en la Figura 2. En las Figuras 2a y 2c se destaca una apariencia alveolar que posiblemente pertenezca a la estructura inicial de la hoja. En las Figuras $2 b$ y $2 d$
The ash obtained was analysed by SEM, with the results shown in Figure 2. The honeycomb structure visible in Figures $2 a$ and $2 c$ may have been present in the initial straw material. Figures $2 b$ and $2 d$ show the ash particle topography in greater detail. Note that the ash obtained

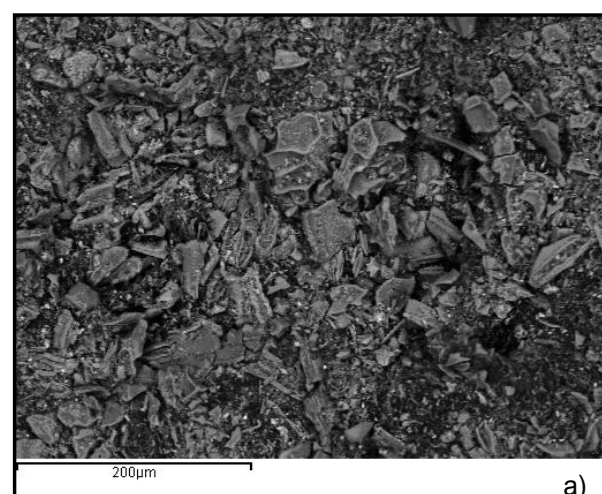

a)

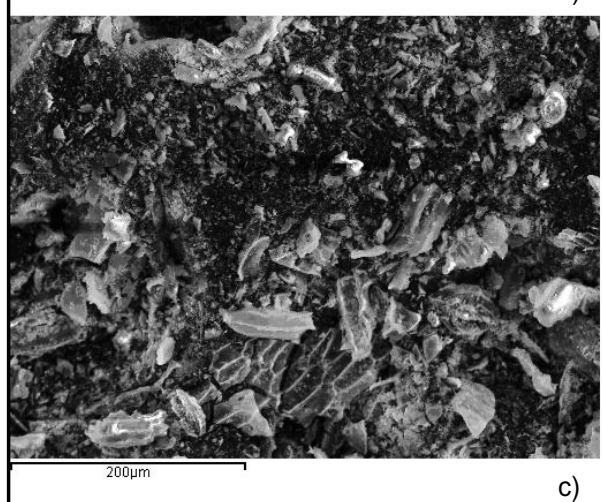

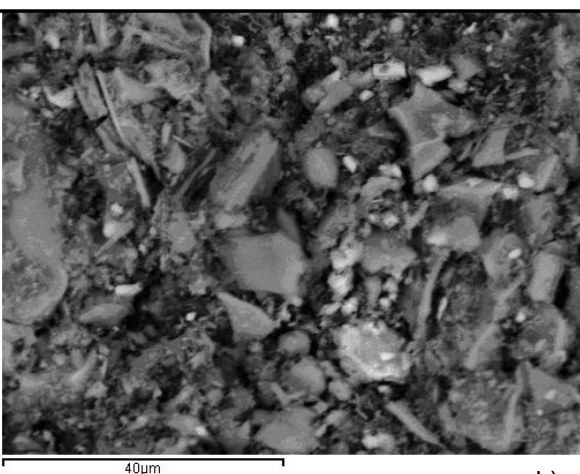

b)

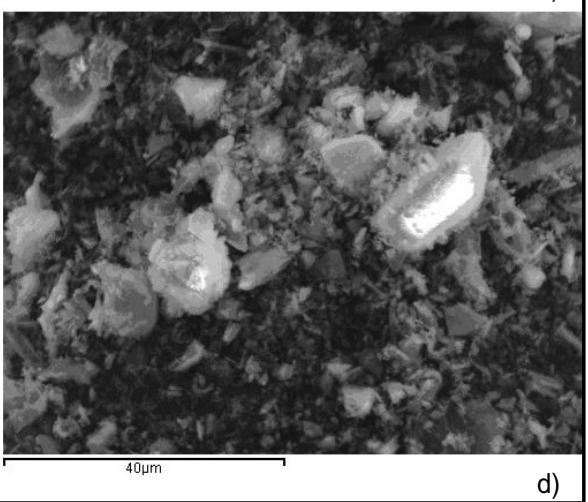

Figura 2. MEB de ceniza obtenida mediante el proceso de calcinación A: (a) X250, (b) X1500; y proceso de calcinación C: (c) X250, (d) X1500.

Figure 2. Scanning electron micrograph of ash obtained with calcination processes A [(a) X250, (b) X1500] and C [(c) X250, (d) X1500]. 
es posible observar en mayor detalle la topografía de las partículas de la ceniza; se observa en la ceniza obtenida mediante el proceso de calcinación $\mathrm{C}$ una topografía de tipo esponjoso (5); mientras que para la ceniza obtenida de la calcinación directa de la hoja de caña (proceso A), además de presentar esta misma topografía en menor proporción, se aprecian zonas con formas agudas lo que indica un mayor grado de cristalinidad respecto a la ceniza obtenida con el proceso C.

La distribución granulométrica de la ceniza, antes y después del proceso de molienda, al igual que la del cemento sin adición se aprecian en la Tabla 3 y Figura 3. Cabe anotar que la distribución de los tamaños acumulados de la ceniza molida y del cemento resultaron ser muy similares, al igual que su diámetro medio de partícula, D $(4,3)$. with incineration process $C$ was more sponge-like (5). The ash obtained by directly incinerating the sugar cane straw (process $A$ ), while exhibiting the same topography (although less intensely), also contained sharp narrow particles, an indication of greater crystallinity than in the ash obtained with process $C$.

The particle size distribution of the ash before and after grinding as well as of the unadditioned cement is shown in Table 3 and Figure 3 The cumulative sizes of the ground ash and the cement were very similar, as were their mean particle diameters, $D$ (4.3).

Tabla 3 / Table 3

Valores de distribución granulométrica.

Particle size distribution.

\begin{tabular}{|c|c|c|c|}
\hline Distribución / Part. size & $\begin{array}{c}\text { Cemento sin adición / } \\
\text { Unadditioned cement }\end{array}$ & $\begin{array}{c}\text { CHC molida 1 hora / } \\
\text { SCSA ground for 1 hour }\end{array}$ & $\begin{array}{c}\text { Arena de Ottawa molida 9 horas / } \\
\text { Ottawa sand ground for 9 hours }\end{array}$ \\
\hline$d(0.1)(\mu \mathrm{m})$ & 5.2 & 5.6 & 3.4 \\
\hline$d(0.5)(\mu \mathrm{m})$ & 22.8 & 17.7 & 15.9 \\
\hline$d(0.9)(\mu \mathrm{m})$ & 53.1 & 52.7 & 41.4 \\
\hline$D(4.3)(\mu \mathrm{m})$ & 26.6 & 24.2 & 19.6 \\
\hline
\end{tabular}

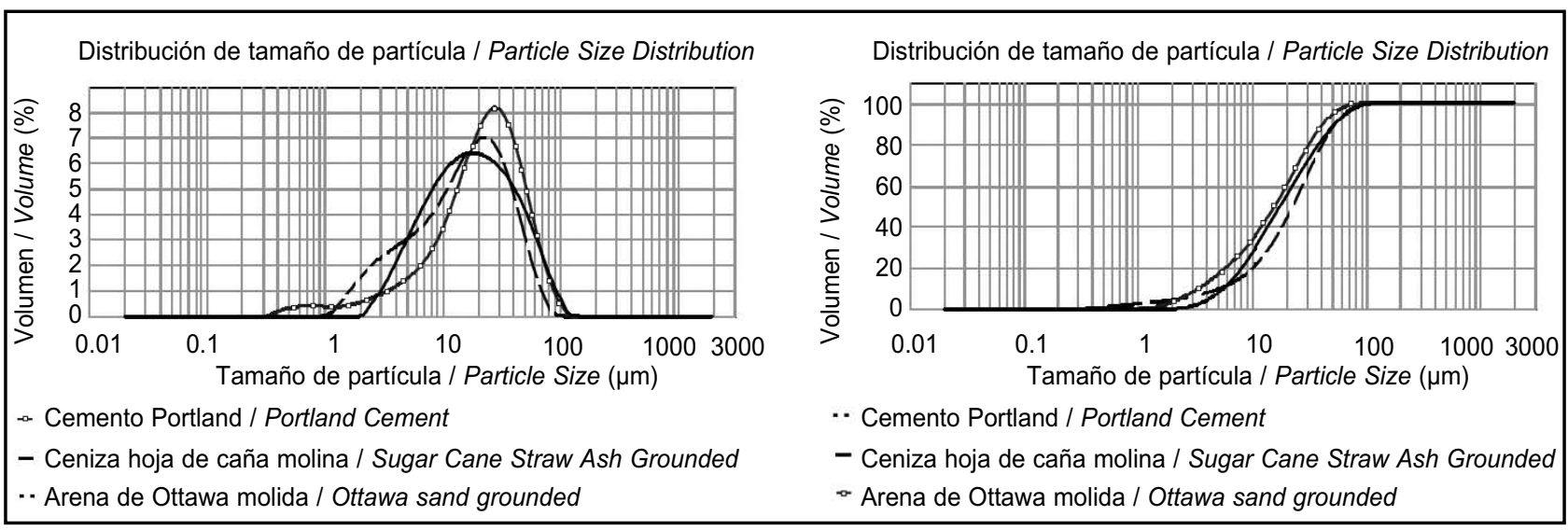

Figura 3. Distribución granulométrica ceniza hoja de caña molida, cemento sin adición y arena de Ottawa molida. Figure 3. Particle size distributions of ground sugar cane straw ash, Portland cement and ground Ottawa sand.

\subsection{Evaluación de la aptitud puzolánica de la ceniza}

\subsubsection{Actividad puzolánica o ensayo de Frattini}

La evaluación por el método químico de actividad puzolánica o ensayo de Frattini se refiere a la cantidad máxima de hidróxido de calcio con la que la puzolana se puede combinar y a la velocidad con la cual ocurre esta reacción. Ésta depende de la naturaleza y proporción de las fases activas presentes en la puzolana, de la relación cal-puzolana de la mezcla, de la finura (o superficie específica) de

\subsection{Evaluation of ash pozzolanicity}

\subsubsection{Pozzolanicity or Frattini test}

The chemical assessment of pozzolanicity, i.e., the Frattini test, measures the maximum amount of calcium hydroxide with which the pozzolan can combine and the rate at which the reaction takes place. These parameters depend on the nature and proportion of the active phases present in the pozzolan, the lime-pozzolan ratio in the mix, the fineness (or specific surface) of the pozzolan and 
la puzolana y de la temperatura de reacción. A medida que las muestras evaluadas se encuentran por debajo de la curva de saturación (Figura 4), las muestras presentan una mayor aptitud a reaccionar con el hidróxido de calcio, $\mathrm{Ca}(\mathrm{OH})_{2}$. Sin embargo, esto no indica que tan adecuado sea el material para desarrollar resistencias mecánicas, inhibir las reacciones entre álcalis-agregados, bajar el calor de hidratación, u otras características que puede proporcionar un material puzolánico. Esto se debe a que las condiciones en que se desarrolla la evaluación química son muy diferentes de las que se tienen en un mortero $u$ hormigón y no es posible establecer una relación entre el efecto sobre las propiedades que desarrolla en el mortero y su comportamiento químico frente al $\mathrm{Ca}(\mathrm{OH})_{2}$. Teniendo en cuenta los resultados presentados en la Figura 4, se puede determinar que a los siete días se presenta una actividad puzolánica moderada, actividad que se aprecia en mayor proporción a edad de 28 días. the reaction temperature. The farther the samples are below the saturation curve (Figure 4), the greater their reactivity with calcium hydroxide $\mathrm{Ca}(\mathrm{OH})_{2}$. The findings, however, provide no indication of mechanical strength development, inhibition of the alkali-aggregate reaction, reduction of heat of hydration or other properties associated with pozzolanic materials. The reason is that the conditions in which chemical evaluation is performed differ substantially from the conditions prevailing in mortar or concrete and no relationship can be established between the effect on the properties developed in the mortar and chemical behaviour in terms of $\mathrm{Ca}(\mathrm{OH})_{2}$. Further to the results shown in Figure 4, pozzolanicity was moderate after 7 days and somewhat more intense after 28.

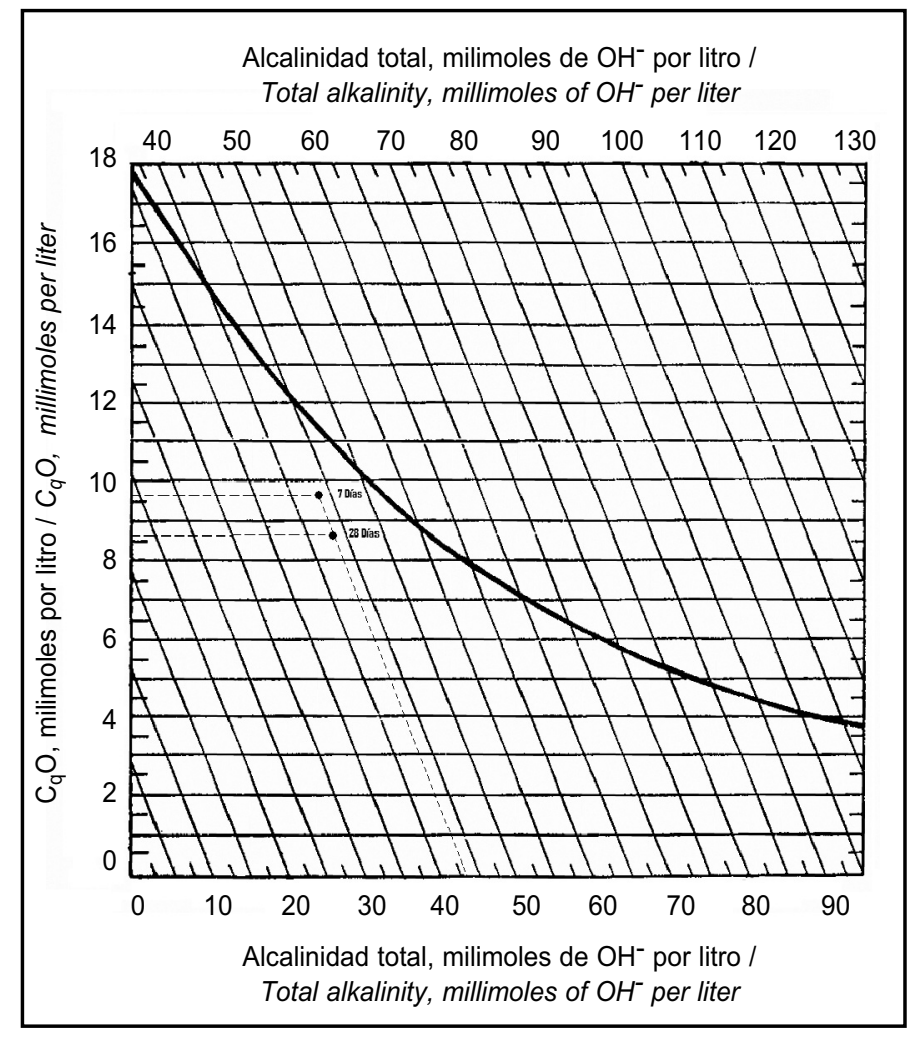

Figura 4. Ensayo de puzolanicidad segun Frattini. Figure 4. Pozzolanicity (Frattini test).

\subsection{2. Índice de Actividad Puzolánica}

Las mezclas de mortero preparadas para la evaluación del Índice de Actividad Puzolánica (IAP), el cual se expresa como la relación entre la resistencia de un mortero con adición y la del mortero sin adición, se realizaron siguiendo las indicaciones de la Norma ASTM C311-07 (20), es decir, se adicionó un $20 \%$ de la puzolana respecto al peso del cemento. Los valores de la resistencia mecánica obtenidos

\subsubsection{Pozzolanic activity index}

The pozzolanic activity index (PAI), which is expressed as the ratio between the strength values of additioned and unadditioned mortar, was found in mixes prepared as described in standard ASTM C311-07 (20), i.e., adding $20 \%$ pozzolan by cement weight. The 7- and 28-day mechanical strength values obtained are given in Table 4. Further to the PAI values given in the table, 
para edades de siete y 28 días se muestran en la Tabla 4. Según los valores de IAP a siete y 28 días, presentados en la misma Tabla, se puede afirmar que la adición de ceniza de hoja de caña sí tiene aptitud para ser utilizada como una adición puzolánica, ya que estos valores se encuentran por encima del $75 \%$, valor límite definido en la Norma ASTM C618-08 (22). sugar cane straw ash is apt for use as a pozzolanic addition, for the values found were above $75 \%$, the threshold established in standard ASTM C618-08 (22).

Tabla 4 / Table 4

Valores de resistencia mecánica en morteros IAP a 7 y 28 días. Mechanical strength and pozzolan activity index values in 7- and 28-day mortars.

\begin{tabular}{|c|c|c|c|c|}
\hline Mortero / Mortar & $\begin{array}{c}\text { Resistencia 7 días }(\mathbf{M P a}) / \\
\text { 7-Day strength }(\mathbf{M P a})\end{array}$ & $\begin{array}{c}\text { Resistencia 28 días }(\mathbf{M P a}) / \\
\text { 28-Day strength (MPa) }\end{array}$ & IAP $_{\text {7dias }} / \mathbf{P A I}_{\text {days }}$ & IAP $_{\text {28dias }} / \mathbf{P A I}_{\mathbf{2 8 d a y s}}$ \\
\hline Patrón / Control & 28.14 & 40.17 & - & - \\
\hline Adicionado / Additioned & 21.91 & 32.12 & 77.86 & 79.96 \\
\hline
\end{tabular}

\subsubsection{Método de Feret}

Para la aplicación de este método se prepararon morteros siguiendo las Normas NTC 111 y $112(23,24)$ a fluidez constante $110 \pm 5$ y moldeados en cubos de 2 pulgadas de arista. La adición utilizada como inerte fue arena de Ottawa, la cual se sometió a un proceso de molienda por nueve horas en orden a obtener un tamaño de partícula similar al de la adición; su distribución granulométrica se presenta en la Tabla 3 y Figura 3. La relación agua/cemento fue la misma para las parejas de morteros con adición de ceniza de caña y con arena de Ottawa molida e incorporada en el mortero a igual porcentaje de sustitución de cemento Portland. En la Tabla 5 se presentan los requerimientos de agua en cada caso, se observa que al incrementar el porcentaje de ceniza de hoja de caña los morteros adicionados requieren mayor cantidad de agua para mantener la fluidez constante, esto es atribuido a la estructura porosa de las partículas de ceniza; la relación encontrada fue de naturaleza lineal: $Y=0,024 X+0,5801\left(R^{2}=0,968\right)$, donde $X$ representa el porcentaje de adición. Este resultado es análogo al

\subsubsection{Feret method}

Mortars were prepared as recommended in Colombian standards NTC 111 and $112(23,24)$, with a constant flowability of $110 \pm 5$ and poured into 2-inch cubic moulds. The inert addition used was Ottawa sand, which was ground for 9 hours to obtain a particle size similar to the size of the ash grains. The particle size distribution of the sand is shown in Table 3 and Figure 3. The same water/cement and replacement ratios were used for each sugar cane straw ash - ground Ottawa sand pair. Table 5 gives the water requirements in each case. The higher the percentage of sugar cane straw ash in the additioned mortars, the higher was the amount of water needed to maintain constant flowability. This could be attributed to the pore structure of the ash particles. The relationship was found to be linear: $Y=0.024 X+0.5801$ $\left(R^{2}=0.968\right)$, where $X$ is the replacement ratio. This result is consistent with the findings reported in an earlier study (25), which established a linear relationship between the amount of water needed to maintain constant workability and the amount of rice husk ash (an

Tabla 5 / Table 5

Requerimiento de agua de los morteros. Water requeriment of mortars.

\begin{tabular}{|c|c|c|c|}
\hline Material / Material & $\begin{array}{l}\text { Porcentaje de sustitución / } \\
\text { Replacement ratio }\end{array}$ & Fluidez / Flowability & Relación $(\mathrm{a} / \mathrm{c}) / W / c$ ratio \\
\hline \multicolumn{2}{|c|}{ Patrón (EMA 0\%) / Control (0 \% OPC) } & 111 & 0.5745 \\
\hline \multirow{4}{*}{ Ceniza / Ash } & EMA $5 \%$ & 115 & 0.5902 \\
\hline & EMA $10 \%$ & 113 & 0.6058 \\
\hline & EMA $20 \%$ & 115 & 0.6400 \\
\hline & EMA $40 \%$ & 107 & 0.6700 \\
\hline \multirow{4}{*}{ Arena de Ottawa / Ottawa sand } & AOM 5\% & - & 0.5902 \\
\hline & AOM $10 \%$ & - & 0.6058 \\
\hline & AOM $20 \%$ & - & 0.6400 \\
\hline & AOM $40 \%$ & - & 0.6700 \\
\hline
\end{tabular}

- No se pudo determinar por su alta fluidez. / Too fluid to be determined. 
obtenido por M. A. Cincotto (25), quien reporta la existencia de una relación lineal entre la cantidad de agua requerida para mantener una trabajabilidad constante y la cantidad de ceniza de cascarilla de arroz incorporada en el cemento, residuo agroindustrial similar al evaluado en la presente investigación.

La resistencia mecánica a la compresión fue evaluada según la Norma NTC 220 (26) a edades de curado normal de 28 y 60 días, obteniendo los valores esquematizados en la Figura 5. En ésta se aprecia que a medida que aumenta el porcentaje de sustitución del cemento por inerte de arena de Ottawa, disminuye la resistencia mecánica, esto es atribuido al incremento en la relación agua/cementante para cada porcentaje de sustitución y al efecto de dilución del inerte al tener una menor cantidad de cemento necesario para reaccionar y formar productos de hidratación que contribuyen al aumento de la resistencia mecánica. Aunque existe una excepción para un $5 \%$ de adición; debido quizá a que la finura y la proporción del sustituyente ayudan con sus granos a ocupar los espacios intersticiales entre los granos del cemento, complementando así la granulometría, lo cual se ve reflejado en un ligero aumento de la resistencia mecánica, esto es un indicativo de su actuación como filler o relleno en la mezcla.

Por lo contrario, a medida que aumenta el porcentaje de sustitución del cemento por ceniza de hoja de caña, existe un incremento en la resistencia mecánica respecto al tiempo de curado comparada con el patrón hasta un $20 \%$ de adición. La mayor resistencia ocurre para un porcentaje de sustitución del $20 \%$ a edades de 28 días y del agroindustrial by-product similar to the material studied here) added to the cement.

The compressive strength values found in 28- and 60day specimens as stipulated in Colombian standard NTC 220 (26) are charted in Figure 5. As the figure shows, mechanical strength declined with rising Ottawa sand replacement ratios. This was attributed to the rise in the water/cement ratio with increasing proportions of sand and the diluting effect of the inert material, whose addition reduced the amount of cement present and hence the reactivity needed to form the hydration products that contribute to mechanical strength. The 5\% addition constituted an exception, however. A possible explanation is that in view of the fineness and proportion of the replacement, its particles occupied the interstitial space between the cement grains, thereby acting as a filler in the resulting mortar.

On the contrary, at replacement ratios of up to $20 \%$, the higher the proportion of sugar cane straw ash, the higher was the mechanical strength compared to the control at each age. The highest 28-day strength was found with a replacement ratio of $20 \%$ and the highest 60 -day strength with a ratio of $10 \%$, despite the increase

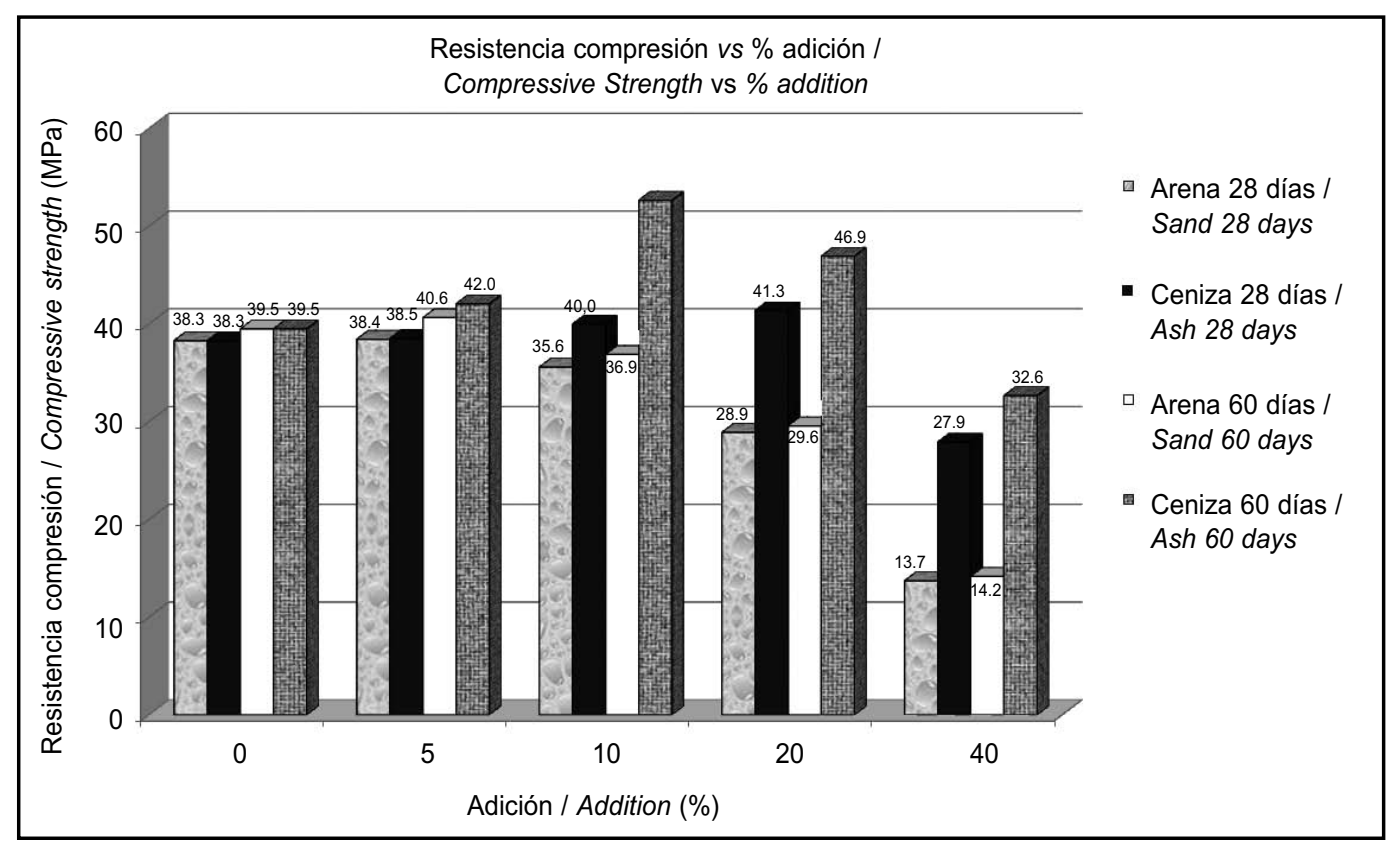

Figura 5. Resistencia a la compresión a 28 y 60 días de curado. Figure 5.28 and 60 day compressive strength. 
$10 \%$ a edades de 60 días, a pesar del incremento en la relación agua/cementante para cada porcentaje de sustitución. Para porcentajes de adición del $40 \%$ la resistencia disminuyó comparada con el patrón tanto a los 28 como a los 60 días. Sin embargo, cabe destacar que en los porcentajes de adición de ceniza elevados (EMA 40\%) a pesar de que su resistencia está por debajo del patrón (EMA 0\%), las resistencias son muy superiores a los adicionados con arena de Ottawa (AOM 40\%). Esto da un indicio de que la ceniza sí es reactiva y que ayuda a formar productos de hidratación que contribuyen al aumento de la resistencia mecánica. Lo anterior corrobora que la ceniza de hoja de caña presenta un marcado efecto puzolánico.

En la Figura 6 se puede evidenciar claramente el comportamiento puzolánico a los 28 y 60 días de curado. En este gráfico se aprecia que, para cualquier orden de adición, la curva representativa de la puzolana se encuentra situada por encima de la del inerte, mostrando un máximo incremento resistente por efecto de la puzolanicidad entre el 10 y el $20 \%$ de adición de ceniza de hoja de caña. in the water/cement ratio needed in the additioned cements. With replacement ratios of $40 \%$, both 28 - and 60 -day strength values were lower than in the control. Nonetheless, at that ratio ( $40 \%$ OPC) strength was much higher than in the mortars containing Ottawa sand as an addition ( $40 \%$ GOS). These findings support the existence of ash reactivity and its role in the formation of the hydration products that contribute to mechanical strength. The foregoing corroborated the significant pozzolanic effect of sugar cane straw ash.

Figure 6 provides clear evidence of pozzolanic behaviour in the 28-and 60-day specimens. The graph shows that, at all the replacement ratios, the pozzolan curve was positioned above the inert addition curve. The maximum pozzolan-induced rise in strength was observed for replacement ratios of 10 to $20 \%$.

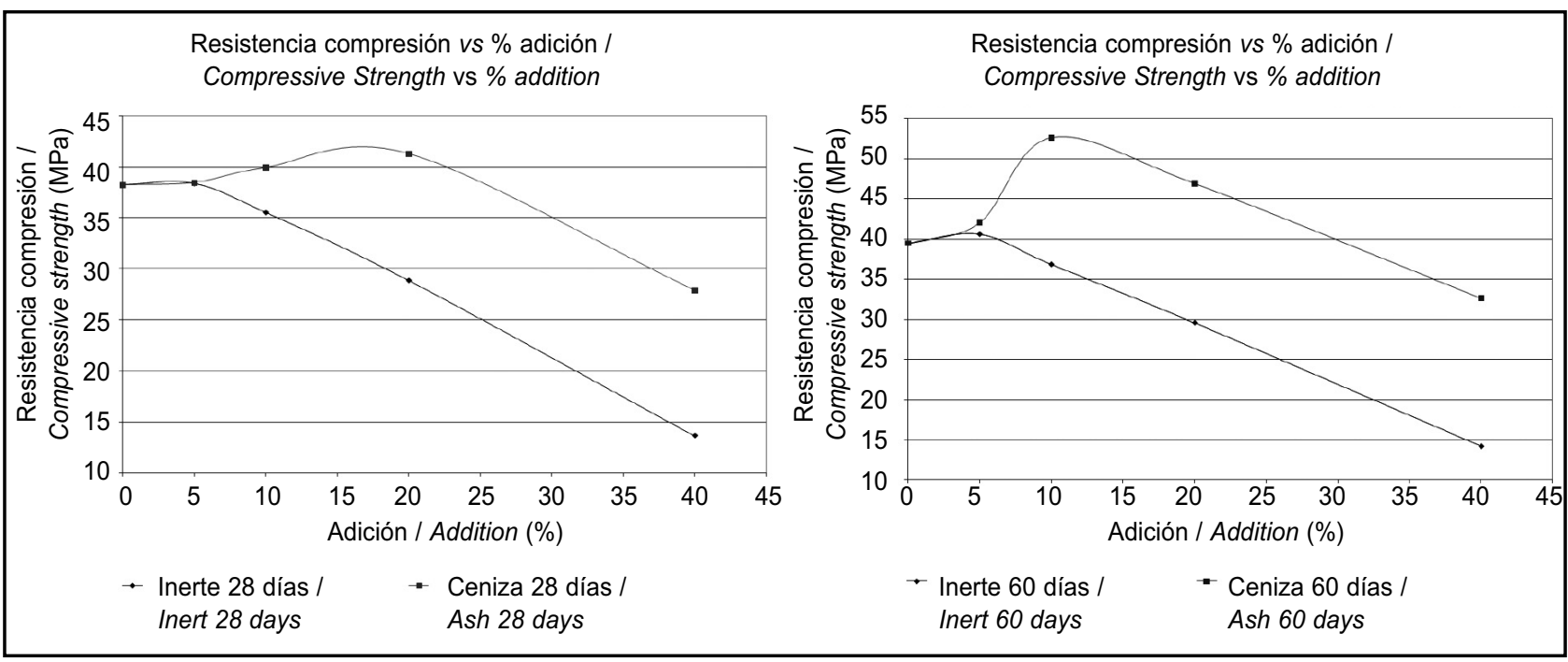

Figura 6. Resistencia a la compresión a 28 días vs porcentaje de adición. Figure 6. 28- and 60 strength vs replacement ratio.

Con base en los resultados de resistencia a la compresión se halló el coeficiente K de Feret (21), con el fin de cuantificar la calidad puzolánica de la ceniza. Estos coeficientes de energía del conglomerante, calculados de acuerdo a la ecuación [1], se reportan en la Tabla 6 . En general, los coeficientes energéticos de los morteros adicionados con material inerte presentan valores muy similares al patrón ( $0 \%$ de adición) y en más alto grado a medida que aumenta el porcentaje de adición; por el contrario, los morteros que contienen ceniza de caña presentan valores crecientes de estos coeficientes en la
These compressive strength findings were used to find the Feret $K$ coefficient (21), a measure of the pozzolanic quality of the ash. These coefficients, calculated from equation [1], are given in Table 6. As a rule, the Feret's $K$ coefficients for mortars additioned with inert material exhibited values similar to the findings for the control ( $0 \%$ addition), and the greater the replacement ratio, the closer was the similarity. By contrast, the mortars containing sugar cane straw ash had higher $K$ coefficient values at higher concentrations of ash and older ages. The $K$ values in mortars with $40 \%$ ash were double the 
medida en que se tiene mayor concentración de ceniza y aumenta la edad de curado. Así, para porcentajes de adición de ceniza del $40 \%$ los valores de $K$ duplican los obtenidos en los morteros de referencia y/o adicionados con inerte. Esto indica la elevada actividad puzolánica del material evaluado. values found for the control or sand-additioned mortars. This was an indication of the pozzolanic activity of the material assessed.

Tabla 6 / Table 6

Coeficientes $\mathrm{K}$ de Feret.

Feret $K$ coefficients.

\begin{tabular}{|c|c|c|c|c|c|c|}
\hline Adición / Addition & $\begin{array}{c}\text { Coeficiente } K \text { de Feret o Coeficiente } \\
\text { de energía del conglomerante / } \\
\text { Feret's } K \text { coefficient }\end{array}$ & $0 \%$ & $5 \%$ & $10 \%$ & $20 \%$ & $40 \%$ \\
\hline Inerte/ Inert & $\mathrm{K}_{28 \text { dias }} / K_{28 \text { days }}$ & 306 & 341 & 351 & 364 & 304 \\
\hline Inerte/ Inert & $\mathrm{K}_{60 \text { dias }} / K_{60 \text { days }}$ & 316 & 361 & 364 & 372 & 314 \\
\hline Adición / Addition & $\begin{array}{c}\text { Coeficiente } K \text { de Feret o Coeficiente } \\
\text { de energía del conglomerante / } \\
\text { Feret's K coefficient }\end{array}$ & $0 \%$ & $5 \%$ & $10 \%$ & $20 \%$ & $40 \%$ \\
\hline Ceniza / Ash & $\mathrm{K}_{28 \text { días }} / K_{28 \text { days }}$ & 306 & 342 & 394 & 520 & 618 \\
\hline Ceniza / Ash & $\mathrm{K}_{60 \text { días }} / K_{60 \text { days }}$ & 316 & 373 & 519 & 591 & 723 \\
\hline
\end{tabular}

\section{CONCLUSIONES}

De acuerdo a los análisis de caracterización realizados en este proyecto, se determinó que el proceso de calcinación más adecuado en aras a obtener una ceniza con alto grado de amorficidad es donde se realiza una combustión de la hoja a temperaturas menores de $427^{\circ} \mathrm{C}$ y una calcinación controlada a una temperatura máxima de $700{ }^{\circ} \mathrm{C}$ con un tiempo de permanencia de dos horas.

Los diferentes métodos aplicados indicaron que la ceniza de la hoja de caña de azúcar presenta actividad puzolánica a porcentajes de adición inferiores al 40\%.

El máximo incremento resistente por efecto de la puzolanicidad se obtiene entre el 10 y el $20 \%$ de adición de ceniza de hoja de caña.

\section{AGRADECIMIENTOS}

Los autores quieren agradecer a la Universidad del Valle (Colombia), al Centro de Excelencia en Nuevos Materiales (CENM), a la Acción CYTED de Coordinación de Proyectos de Investigación 307ac0307 Residuos Agro-Industriales: Fuente Sostenible de Materiales de Construcción (VALORES), y al Instituto de Tecnología de Materiales de la Universidad Politécnica de Valencia por el apoyo brindado para el desarrollo de este estudio.

\section{CONCLUSIONS}

The analyses conducted in this study revealed that the most suitable incineration process for generating highly amorphous ash consisted of pre-combustion at temperatures below $427^{\circ} \mathrm{C}$ followed by controlled incineration for two hours at $700{ }^{\circ} \mathrm{C}$.

The various methods used showed that sugar cane straw ash exhibited pozzolanic activity at replacement ratios of under $40 \%$.

The highest pozzolanicity-induced increase in strength was obtained when sugar cane straw ash was added at a rate of 10 to $20 \%$.

\section{ACKNOWLEDGMENTS}

The authors wish to thank Valle University, Colombia, the Centre for New Materials Excellence (CENM), the CYTED Programme for Research Project Coordination (307ac0307, agroindustrial by-products - sustainable source of construction materials (VALORES)) and the Polytechnic University of Valencia's Materials Technology Institute for the support provided for this study. 


\section{BIBLIOGRAFÍA / BIBLIOGRAPHY}

(1) Informe Anual de ASOCAÑA 2008-2009 - Sector Azucarero Colombiano, 11 de junio de 2009. 93 pp.

(2) Salas, A.; Delvasto, S.; Mejía de Gutiérrez, R.; Lange, D.: "Comparison of two processes for treating rice husk ash for use in high performance concrete", Cem. and Concr. Res., vol. 39, Issue 9 (2009), pp. 776-778.

(3) Arcos, A.; Maciaz, D.; Mosquera, P.; Rodríguez, J. E.: "Fuentes vegetales de SiO2: cascarilla de arroz", en Memorias del III Congreso Internacional de Materiales - Simposio Materia 2005 - VIII Congreso Nacional de Corrosión y Protección; Cartagena de Indias, Colombia: 2005, sep. 11-16; Medellín: Universidad de Antioquia; 2005. B-5, 16 pp.

(4) Kantiranis, N.: "Re-cycling of sugar ash: a raw feed material for rotary kilns", Waste Management. vol. 24, Issue 10 (2004), pp. 9991004. doi:10.1016/j.wasman.2004.07.009, PMid:15567665

(5) Martirena, J. F.; Betancourt, S.; Middendorf, B.; Rubio, A.; Martínez, J.; Machado, J.; González, R.: "Propiedades puzolánicas de desechos de la industria azucarera (primera parte)", Mater. Construcc., vol. 50, no 260 (2000), pp. 71-78. doi:10.3989/mc.2000.v50.i260.392 (6) Martirena, J. F.; Betancourt, S.; Middendorf, B.; Rubio, A.; Martínez, J.; Machado, J.; González, R.: "Propiedades puzolánicas de desechos de la industria azucarera (segunda parte)", Mater. Construcc., vol. 51, no 261 (2001), pp. 67-72. doi:10.3989/mc.2001.v51.i261.381

(7) Martirena, J. F.; Middendorf, B.; Gehrke, M.; Budelmann, H.: "Use of wastes of the sugar industry as pozzolana in lime-pozzolana binders: study of the reaction", Cem. and Concr. Res., vol. 28, Issue 11 (1998), pp. 1525-1536. doi:10.1016/S0008-8846(98)00130-6

(8) Singh, N. B.; Singh, V. D.; Rai, S.: "Hydration of bagasse ash-blended Portland cement", Cem. and Concr. Res., vol. 30, Issue 9 (2000), pp. 1485-1488. doi:10.1016/S0008-8846(00)00324-0

(9) Ganesan, K.; Rajagopal, K.; Thangavel, K.: "Evaluation of bagasse ash as supplementary cementitious material", Cem. and Concr. Compos., vol. 29, Issue 6 (2007), pp. 515-524. doi:10.1016/j.cemconcomp.2007.03.001

(10) Martirena, F.; Middendorf, B.; Day, R. L.; Gehrke, M.; Roque, P.; Martinez, L.; Betancourt S.: "Rudimentary, low tech incinerators as a means to produce reactive pozzolan out of sugar cane straw", Cem. and Concr. Res., vol. 36, Issue 6 (2006), pp. 1056-1061. doi:10.1016/j.cemconres.2006.03.016

(11) Villar-Cociña, E.; Valencia, E.; González, R.; Hernández, J.: "Kinetics of the pozzolanic reaction between lime and sugar cane straw ash by electrical conductivity measurement: A kinetic-diffusive model", Cem. and Concr. Res., vol. 33, Issue 4 (2003), pp. $517-524$. doi:10.1016/S0008-8846(02)00998-5

(12) Frías, M.; Villar-Cociña, E.; Sánchez, M. I.; Valencia, E.: "The effect that different pozzolanic activity methods has on the kinetic constants of the pozzolanic reaction in sugar cane straw-clay ash/lime systems: Application of a kinetic-diffusive model", Cem. and Concr. Res., vol. 35, Issue 11 (2005), pp. 2137-2142. doi:10.1016/j.cemconres.2005.07.005

(13) Frías, M.; Villar-Cociña, E.; Valencia, E.: "Characterisation of sugar cane straw waste as pozzolanic material for construction: Calcining temperature and kinetic parameters", Waste Management, vol. 27, Issue 4 (2007), pp. 533-538. doi:10.1016/j.wasman.2006.02.017, PMid:16714102

(14) Villar-Cociña, E.; Frías, M.; Valencia, E.; Sánchez de Rojas, M.: "Validación de un modelo cinético-difusivo para caracterizar la cinética de reacción puzolánica en sistemas cenizas de paja de caña-arcilla/cal", Mater. Construcc., vol. 55, n 278 (2005), pp. 29-40.

(15) ASTM C-778 06 Standard Specification for Standard Sand.

(16) NTC 33 Método para la determinación de la finura del cemento por medio del aparato Blaine de permeabilidad al aire.

(17) NTC 221 Método de ensayo para determinar el peso específico del cemento hidráulico.

(18) Mehta, P. K.: Belgian Patent No. 802909, July 1973.

(19) NTC 1512 Cementos. Ensayo químico para determinar la actividad puzolánica.

(20) ASTM C311-07 Standard Test Methods for Sampling and Testing Fly Ash or Natural Pozzolans for Use in Portland-Cement Concrete.

(21) Papadakis, M.; Venuat, M.: "Fabricación, características y aplicaciones de los diversos tipos de cemento", Barcelona: Editores Técnicos Asociados (1968), pp. 164-166,.

(22) ASTM C618-08 Standard Specification for Coal Fly Ash and Raw or Calcined Natural Pozzolan for Use in Concrete.

(23) NTC 111 Método para determinar la fluidez del mortero de cemento (mesa de flujo).

(24) NTC 112 Mezcla mecánica de pastas de cemento hidráulico y morteros de consistencia plástica.

(25) Cincotto, M. A.; Agopyan, V.; John, V. M.: "Optimization of rice husk ash production", 2nd International Symposium on vegetable plants and their fibres as building materials, Salvador, Brazil, September 1990.

(26) NTC 220 Determinación de la resistencia de morteros de cemento hidráulico usando cubos de 50 mm de lado. 